\title{
Bureaucracy reform: open government partnership as a change strategy in Bojonegoro regency?
}

\author{
Haidar Fikri ${ }^{a}$, Didik G Suharto ${ }^{\mathrm{a}}$, Rino Ardhian Nugroho ${ }^{\mathrm{a}} *$ \\ ${ }^{a}$ Sebelas Maret University, Solo, Central Java, Indonesia
}

\section{ARTICLE INFORMATION}

\section{Article history:}

Data submission : 12 February 2018

$1^{\text {st }}$ revision: 10 October 2018

Accepted: 16 December 2018

Available online: 30 December 2018

Keywords: bureaucracy reformation, Open Government Partnership, transparency, participation

\section{ABSTRACT}

A complicated and rigid public service is the characteristic of bureaucracy. Public service that is not transparent and accountable will create a bureaucracy as an ineffective and inefficient organization. Open Government Partnership becomes a strategy implemented by bureaucracy in Bojonegoro regency. This strategy has not been implemented yet. This research is aimed to explore how Bojonegoro's bureaucracy solves the problem by using Open Government Partnership in the context of public service. A qualitative-descriptive method is used in this research as a data analysis in the field. The process of collecting data is supported by observation, literature review, interview, and documentation. The result of this research is strategy of Open Government Partnership using variables such as; transparency, participation and collaboration to create a successful bureaucracy reformation. Transparency also becomes an essential value on each service and policy implementation because the government involves the society to decide a case. The government conducts some collaboration in order that all society elements can work together with them to realize bureaucracy in Bojonegoro regency.Strategy of Open Governement Partnership takes Bojonegoro regency to represent Indonesia in the event of innovation promotion of OGP in the international level.

2018 FIA UB. All rights reserved.

\section{1) Introduction}

The ending of the new order and the birth of reformation bring the renewalto the creation of better government. The renewal can be seen through the reformation spirit to change the culture and system of centralization into decentralization. Decentralization is expected to reform the function of governmental bureaucracy to be better. As a public organization, governmental bureaucracy is different with private organization which is more oriented to the profit. Public bureaucracy is expected to have a function to give service to the society. The service must be more responsive as the implementation of decentralization of regional autonomy.

Governmental decentralization in the concept of regional autonomy is a way to create a responsive and democratic service. Decentralization is meant as a broad, real and responsible autonomy concept. It conducts the autonomy to the society on the nearest level. The aim of giving regional autonomy is to empower the region and the residents and encourage the residents' initiation and role in building the nation (Suhirman, 2004).

According to Litvack \& Seddon (1999), decentralization is "transfer of authority and responsibility for public function from central to subordinate or quasi-independent government organization or the private sector ". The definition above can be stated in the context of governmental relation that represents the state with other entities. They include organization of sub-national and semi-free government and private sector. Based on the view of policy and administration, states that decentralization is meant as transferring plan, taking decision or administrative authority from central government to the organizations in the field, local administrative units, semi-autonomy organization and local government or non-governmental organization" (Cheema \& Rondinelli, 1983). According to Hellmut Wollman (2007), decentralization has intrinsic political implication which is functioned to subnational institution with its strength and function (resources). 
Basically, the national building emphasizes on the aspect of humanity values such as; support the living survival and the ability to fill living needs, self-esteem and the feeling to respect our self and not to become a tool for others, and free from oppression and slavery. Besides that, the meaning of building is the ability of somebody to influence their future that consists of capacity, justice, the growth of rule and authority and being dependent to each other (Todaro, 2000).

The national building is a multidimensional processes that both speeding acceleration of economy growth and ensuring the process of big changes towards social structure, behavior and national institution. The process will relate directly to the public service. Public service defines as an activity conducted by governmental institution both in the central and regional government, state owned enterprise and regional owned enterprise. The activity can be done through things or service to fulfill the needs based on the law rule. The practice of public service is one of the realizations of state apparatus function as civil and state servant. This service function is directed to fill the needs of society and create social justice in society. Therefore, the government can create a better living to their citizens (Ratminto and Septi, 2005). Thus, the foundation of public service is to give good service to the society as a realization of duty as civil servant.

Poverty, unaccountable and not transparent public service and the increase of corruption become challenges to the government in Indonesia. Regional government as the lowest level of civil servant has the strategy to complete the problem. The problem is because of the bad calculation managing and the role of government is not optimal in building transparency and accountability. If the government is opened and accountable to distribute the calculation, the problem can be solved. Bureaucratic reformation is one of strategies chosen by the government to solve the problem. The implementation of reformation is the openness of the government to the citizens which is usually called as Open Government Partnership.

Open government is an intellect government in solving problems and giving service to the citizens. The motivation encourages Indonesian government to join and become one of the founders of global movement of Open Government Partnership (OGP). It was launched in September, 2011 (Book of OGP Bojonegoro, 2016). Indonesian government views the openness as the basis of modern government and becomes a key to open the potential of Indonesia in some sectors such as economy, public service, and innovation to be a progressive, equitable and prosperous state.

Open government or Open Government Partnership (OGP) is a voluntary international initiative of multi sides. The initiative is aimed to ensure the concrete commitment of government to the citizens in promoting openness, empowering the society, omitting corruption and using new technology to strengthen governmental management (Book of OGP Bojonegoro, 2016). Program of Open government partnership of Indonesia is represented by Bojonegoro regency.

The government of Bojonegoro regency has a commitment to the opened public information through the law no. 14 of 2008 about the opened public information established in April 30th 2008. After the release of the law on opened public information, there are various innovative programs implemented in Bojonegoro regency. The innovative program related to the opened public information is interactive dialog that connects the society and the government to deliver the participation.

According to the law policy, it can be stated that the government of Bojonegoro regency has a strong commitment towards opened public information. It is based on the principle that openness is the citizens' needs and human right to know. The government of Bojonegore regency has determined several regulations related to the implementation of opened public information, such as:

a) The regulation of Bojonegoro regency No 30 of 2013 about building information management based on public participation in Bojonegoro regency (Regulation of Regent of Bojonegoro no 30 of 2013); and

b) The regional regulation of Bojonegoro regency no 6 of 2012 about transparency of management of income, environment, and social enterprise responsibility to the activity of oil and gas (Regional regulation of Bojonegoro regency no 6 of 2012)

In 2016, the government of Bojonegoro achieved several recognitions from institution that care of the opened public information in both national and international level. In the early of 2016, "Seknas"of Indonesian Open Government proposed three cities such as Banda Aceh, Jakarta, and Bojonegoro as pilot project to join the competition of Open Government in the international level. The competition was held by Open Government Partnership (OGP). It consisted of 65 countries. In the competition, Bojonegoro was chosen as the sampling of OGP with 15 other countries such as Seoul (South Korea), Paris (France), Buenos Aires (Argentina), San Paulo (Brazil), Tbilisi (Goergia), and etc (INFID, 2016). Based on its achievement, Bojonegoro can prove its strong commitment to conduct OGP.

Strategy of OGP conducted by Bojonegoro regency is admitted by the ministry of empowerment of state apparatus and bureaucratic reformation. The ministry points the regency as a target to arrange grand design and roadmap of bureaucratic reformation (Sutrisno, 2016). According to HananRahmdi, Bojonegoro is good enough in running its government. Bojonegoro has been chosen as the Top 99 of public service innovation held by the ministry of empowerment of state apparatus and bureaucratic reformation. The innovation is not only admitted in national scope but also in international scope. Therefore, Bojonegoro regency becomes the pilot project of the program.

\section{2) Theory}

\subsection{Bureaucratic Reformation}

The development of bureaucratic concept is actually one of kinds of democratic and aristocratic government as stated by Goumay and Mill. In the 19th century, the theorists like Van Mohl, Olzewski and Le Play tend to 
focus on the citizens' dissatisfaction towards the government and view bureaucracy as a passion of the civil servant to be paid to take a part in others' business (Albrow, 2006). In public administration theory, bureaucracy has several meanings. It is meant that government is run by a biro called officialism, the executive organs of government and public officials either high or low official (Albrow, 2006).

In Indonesian context, governmental institution commonly has long hierarchy, written procedure and operational standard, detailed specialization, and carrier official that becomes the characteristic of Weberian bureaucracy. Therefore, governmental institution is usually called as governmental bureaucracy. The work of governmental bureaucracy is usually bad and disappointing related to the public service. Thus, the citizens view that governmental bureaucracy tends to be negative and creates negative stereotype about the concept of Weberian bureaucracy.

Robbins (2006) cites the ideal bureaucratic concept of Weber that consists of seven elements, such as:

a) Work specialization, all works are conducted in simplicity, routine, and defines the task well;

b) Clear competence hierarchy, is a formal multi-level structure with positional hierarchy and position. Each lower position is under the higher supervision and control;

c) High formality, all members of organization are selected through qualified basis that is demonstrated with training, education and formal training;

d) The decision about the employees' placement is based on the ability. The decision about selection and promotion is based on the qualification technique, the ability and the achievement of the candidates;

e) Impersonality, the sanctions are applied similarly to avoid the involvement of individual personality and members' private preference;

f) Carrier track for the employee, the employees are expected to pursue their carrier in organization. As the reward on their commitment, the employees have positional period. It means that they will be survived even though they are not functioned and their ability is not used anymore; and

g) Organizational life separated from private life, the officials are not free to use their position for their personal need and interest.

Bureaucracy has several functions, like systematical function. This function is certainly conducted effectively. A state government is given an authority to conduct various law regulations. The law is determined by the legislative institution through several regulations of implementation and policy. Practically, problems usually appear. The awkwardness usually happens in implementing the regulations. The awkwardness can be seen on the interpretation literally. Building the law and regulation is viewed through spirit and soul in which it is more required. It means that the approach used is situational approach (Siagian, 2008).

Bureaucratic reformation or public administration to increase the efficiency of public administration includes several probable actions. Several instruments have been discussed based on the regulation of New Public Management. The most prominent instruments are E-
Gov, management of human resources, work and service orientation, and institutional re-organization (decentralization, agency, market mechanism). It aims to repair the external and internal process (Asatryan et al., 2017). Nevertheless, reformation contributes to the unclear efficiency of public administration. However, it emphasizes that the role of administrative reformation in bureaucracy is very essential.

Several reformations in public sector is aimed to increase public's trust and build transparent and accountable government (Cheung, 2013). Besides the relation among reformation, transparency and accountability, corruption can be eradicated with reformation. There is strong relation between corruption theory and reformation of public sector. Many policy sector runs without reference to handle corruption. Reformation of public sector closely relates to the solution of corruption. Economy base in reformation of public sector emphasizes on the need of management structure. It is supposed to be transparent and "checks and balances" which can prevent the abuse of individual position (Fitzsimons, 2009).

\subsection{Open Government Partnership}

In a comparative national study discussed about fiscal sector, we explore the relation among condition and concept of socio-cultural, politic, economy, and open government. It is defined as (a) calculation transparency; (b) participation in calculation process; and (c) responsibility information (Harrison et al., 2014). Components of Open Government Partnership include the revelation of democratic document, human capital, consistent calculation related to the transparency, accountability, and involvement between audit authority and public. E-participation and commitment towards the relation of open government relates to the standard of certain transparency and accountability.

Since the instruction of open government has been launched, the focus is on the launching of technology and data to public. This study explores how the institution constitutes the culture of openness in the governmental institution to improve transparency, participation and collaboration with the functionary of external interest (Ruijer et al., 2016). The discovery shows that the institution admits the importance of institutionalizing the culture of openness to emphasize objective culture called organization culture (Morgan, 2006).

\section{3) Research Method}

The research belongs to descriptive research with qualitative approach. The focus of the research is bureaucratic reformation through the strategy of open government partnership. The location of the research was in Bojonegoro regency. The site of the research was the government of Bojonegoro. Technique of collecting data was conducted through observation, interview, and documentation. Method of analyzing data used analysis of qualitative data by Miles, Huberman and Saldana (2014). 


\section{4) Results and Discussion}

Nowadays, there are several complex problems in government, such as poverty, corruption, and public service that is not appropriate with the regulation, not accountable, and not transparent. Bojonegoro regency is one of governmental decentralizations. It also has some problems. Besides fishpond products, oil mining becomes the main commodity in Bojonegoro. Oil mining cannot absolutely eradicate poverty in Bojonegoro. The residents do not know the fund transparency in government. Therefore, the supervision is difficult to conduct. However, the new leader of Bojonegoro gives better change to the government system. The government of Bojonegoro conducts reformation through strategy of open government as the following:

New strategy was conducted by Bojonegoro government in 2008. The program was aimed to the citizens who wanted to deliver their aspiration through short message and facebook. Then, the regent invited them to have dialog and visitation. The regent also invited "SKPD" in a forum to discuss the problems. In 2011-2012, the government added the communication between citizens and bureaucracy through mass media, radio and suggestion box. The innovation becomes good system if the government can implement it well. Now, the citizens can deliver their critic directly. They can also use social media and electronic. It helps them because they previously do not have any access to share their critic and receive information.

Cheung (2013) states that various reformation of public sector has the aim to improve public trust and build transparent and accountable government. Harrison et al. (2014) also state that open government must show transparency and accountability. Bojonegoro government has conducted bureaucratic reformation through direct and indirect interaction to know their problem and give the report about the government. Therefore, OGP becomes a kind of reformation through the same indicator of two journals above. It is also strengthened with the implementation in Bojonegoro.

The interaction between the government and the citizens will result a thought called idea. Harrison et al. (2014) state that one of indicators in open government partnership is participation. Fitzsimons also shows their same thought that "check and balances" can prevent the abuse of individual position. Through the reality in Bojonegoro, the regent always respects the idea and suggestion from the citizens to keep their participation and prevent the position abuse. Therefore, the indicator of citizens' participation in bureaucratic reformation has been filled by the government in creating a better government system.

The last is about the collaboration conducted by the government by utilizing the technology. It involves all the elements of citizens such as, the academicians, the community and the youth of Bojonegoro. The collaboration is very interesting to discuss. The synergy among civil society, government and private sector becomes a symbol of government implementation with the principle of good governance in Bojonegoro regency. Sedarmayanti (2004) categorizes the governance stakeholders into three. Firstly, state/ government; the conception of governance is basically a state activity and involve the private sector and civil society organization. Secondly, private sector; the actor of private sector includes an active private company with themarket system interaction such as manufacturing, trading, banking, and cooperation. Those belong to the activity of informal sector. Thirdly, civil society; community group in the context of state is basically situated among or in the middle of government and individual which covers both individual and community group. Both interact in social, politic and politic sector. According to Asshiddiqie (2004), the system of modern state that based on law and constitution supremacy, state, market and civil society must have a balance position. It must be connected functionally and support each other. However, the difference among the three is supposed to be essential. All three must not interrupt to other affairs. The three

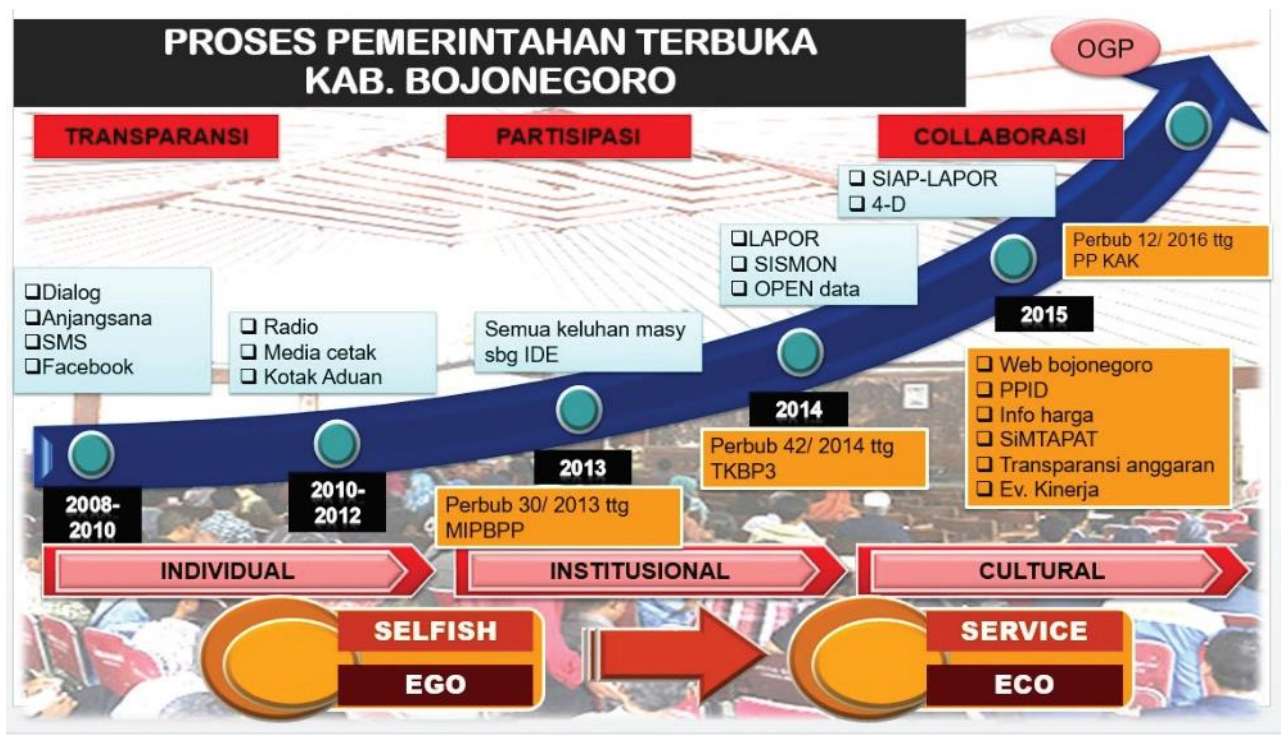

Figure 1. Strategy of Open Government in Bojonegoro Regency 
domains have their own logic and law. They must be implemented strongly, in line and control each other.

Bojonegoro regency has implemented good governance because it involves the collaboration among government, society and private sector. According to Gerald Meier in Abdullah (2002), good governance is a principle to manage a government to give efficient public service, reliable court system, and responsible administration, in which the market mechanism becomes the main consideration in the process of deciding resource allocation. Therefore, the aim of Bojonegoro government is giving a good service to the society.

\section{5) Conclusion}

Bojonegoro government as an open government partnership becomes one of pilot projects of central government. Bojonegoro has implemented the participation of society in taking a policy. The involvement of society in taking a policy becomes a reference of a participation in the government. The government has a strategy to be an open government. By utilizing the technology, the government gives information about finance and governmental program. They also give socialization to the society directly. The synergy of government, civil society and private sector becomes more attractive. The collaboration on the principle of good governance involves three elements. It becomes one of the aims of transparent and accountable government based on the aim of open government partnership.Service system is not only about ego. It must change into public interest, general prosperity (eco) and not being selfish. It must give a service that brings benefits to the public. The indicator of OGP has been fulfilled in exploring on how the institution contributes the culture of openness in governmental institution. It will create transparency, participation, and collaboration with the holder of external interest. The discovery shows that the institution admits the importance of institutionalizing the culture of openness to emphasize objective culture called organization culture. It can be concluded that Bojonegoro government has been successful in running bureaucratic reformation by implementing OGP. Strategy of OGP conducted by Bojonegoro regency is admitted by the ministry of empowerment of state apparatus and bureaucratic reformation. The ministry points the regency as a target to arrange grand design and roadmap of bureaucratic reformation and become the pilot project of OGP.

\section{References}

Abdullah, Kasman. (2002). Penyelenggaraan Pemerintahan Dalam Konsep Good Governance. Jurnal Meritokrasi, Vol. 1, No. 1, pp. 64-75.

Albrow. (2006). Birokrasi, (Cetakan Ketiga). Tiara Wacana, Yogyakarta

Cheung, Anthony B.L. (2013). Public Governance Reform in Hong Kong: Rebuilding Trust and Governability. International Journal of Public Sector Management, Vol. 26, No. 5, pp. 421-436.

Asshiddiqie, Jimly. (2005). Format Kelembagaan Negara dan Pergeseran Kekuasaan dalam UUD 1945. Yogyakarta: FH UII Press.
Asatryan, Zareh., Heinemann, Friedrich., \& Pitlik, Hans. (2017). Reforming the Public Administration: The Role of Crisis and The Power of Bureaucracy. European Journal of Political Economy, , Vol. 48(C), pp. 128-143.

Harrison, Teresa M., \& Djoko Sigit Sayogo. (2014). Transparency, Participation, and Accountability Practices in Open Government: A Comparative Study. Journal Government Information Quarterly, Vol. 31, pp.513-525.

Miles., Huberman., \& Saldana. (2014). Qualitatif Data Analysis. United State of America: Sage Publication

Morgan, G.M. (2006). Images of Organization. Sage Publications, Thousand Oaks, CA.

Ruijer, Erna H.J.M., and Richard F. Huff. (2016). Breaking Through Barriers: The Impact of Organizational Culture on Open Government Reform. Journal Transforming Government: People, Process and Policy, Vol. 10, No. 2, pp.335-350.

Siagian, Sondang. P. (2008). Manajemen Sumber Daya Manusia (Edisi Pertama). Jakarta: Binapura Aksara.

Sedarmayanti. (2004). Good Governance (Kepemerintahan Yang Baik), Cetakan Kedua. Bandung: Mandar Maju.

Suhirman. (2004). Kerangka Hukum Dan Kebijakan Tentang Partisipasi Warga Di Indonesia. Bandung: Ford Foundation.

Todaro, Michael. P. (2000). Pembangunan Ekonomi di Dunia Ketiga, Edisi Ketujuh, Terjemahan Haris Munandar. Jakarta: Penerbit Erlangga.

Fitzsimons, Vincent G. (2009). A Troubled Relationship: Corruption and Reform of the Public Sector in Development. Journal of Management Development, Vol. 28 No. 6, pp. 513-521.

Wollmann, Hellmut. (2007). Devolution of Public Tasks Between (Political) Decentralisation and (Administrative) Deconcentration - in Comparative (European) Perspective. Social Science Institute of Tokyo University, Japan. 